\title{
The Synthesis of a Model of Problem-Based Learning With the Gamification Concept to Enhance the Problem- Solving Skills for High Vocational Certificate
}

\author{
https://doi.org/10.3991/ijet.v16i14.20439 \\ Ratchapol Kladchuen ${ }^{(凶)}$ \\ Pranakorn Commercial Technological College, Bangkok, Thailand \\ pmc.ratchapolegmail.com \\ Jiraphan Srisomphan \\ King Mongkut's University of Technology North Bangkok, \\ Bangkok, Thailand
}

\begin{abstract}
Work in the 21st century places an emphasis on the analytical and problem-solving skills of employees as well as on new adaptability knowledge. Education nowadays needs workers to help develop the skill sets that are necessary for both working and living. This research used synthesis and evaluated formats that would be suitable to the learning model. The problematic base skills together with the gamification concept for strengthening problemsolving skills were utilized with high-level vocational students. The researchers found that the style of learning gained by synthesis emphasizes students' problem-solving in various situations, stimulating and motivating them by using gamification. It involved learning and solving problems using seven steps in the teaching process including: 1) Problem, 2) Analysis, 3) Discovery, 4) Experiment, 5) Presentation, 6) Quest, and 7) Competition. The researchers also concluded that the evaluation of the suitability of the learning model by nine experts with a focus group process was found to be most appropriate. In addition, it identified learning styles that can be applied to teaching and learning appropriately.
\end{abstract}

Keywords - Problem-based Learning, Gamification, Problem-solving Skills, High Vocational Certificate, Thailand

\section{Introduction}

Education is an important tool for developing the quality of a country's citizens. The reason is that citizens are the cornerstone of a country's development in various aspects from the advancement of science and technology to information technology. The advancement can be shown in the transformation which has occurred in society, the economy, culture, and the environment of the country. Therefore, the strategy for developing the quality of people can be seen in the reflection of Thai society. The National Economic and Social Development Plan No. 12 agenda is focusing on the 
sustainability of the Thai people towards becoming a society of wisdom and learning. It emphasizes the development of the population in collaboration with the Center of Development Workforce, which is developing the skills that will meet the needs of the labor market and essential skills to sustain life in the 21st century [1]. In addition, the Department of Education has established the education policy in the National Education Plan 2017-2036, a 20-year long-term plan. This is in line with the economic and social development plan, with the goal of enhancing all learners' skills and encouraging them to seek knowledge in life-long learning as well. The world in the 21 st century emphasizes the adaptability of labor in gaining new knowledge, skills, and conceptual analysis. Therefore, Thai educational management needs to be transformed to develop citizens' analytical thinking as well as applying and synthesizing during learning processes [2].

The learning process must support and challenge learners in developing problemsolving skills. Therefore, educational management needs to be transformed to develop citizens to think, analyze, synthesize, and apply. This is consistent with the Thai national policy and direction of the 21 st century learner, who should be encouraged to face increasingly complex problems [3]. It requires the sustainable development of skills to analyze, synthesize, and summarize complex data that are changing all the time in the digital environment. Learning acquisition is not limited to the classroom, but also is available everywhere. The content of knowledge and skills are abundant in the constantly changing world. Students can seek knowledge everywhere. The learning model of the new generation in the digital age has been a significant leap. There are many online learning methods in the market, such as Massive Open Online Courses (MOOCs), video media (YouTube), computer games (games), social media (social media), and audio media (audiobooks and podcasts) [4].

A survey on the behavior and needs of the new generation found that they liked to learn by themselves. It found that learners enjoy learning when the learning process allows them to be involved in the teaching and learning process. Some 51\% of the learners who are from the new generation like to learn by themselves and are able to create knowledge by themselves through reading books, using the internet, and with online learning, and $23 \%$ of the learners have an interest in workshops and specialized topics. These results are in line with the results of a 2018 internet user behavior survey of Thailand. It found that internet usage behavior of the Thai people was continuing to increase. Thai people spend 10 hours and 5 minutes of time per day on the internet, which was longer than 2017 by about 3 hours 41 minutes per day. The Gen Y users aged between 18 and 37 years ranked the highest usage for four years. In consideration of the usage types, the first rank is reading online books which accounted for $48.27 \%$. This implies that consumer behavior in reading is changing throughout life to become more digital [5].

The Vocational National Educational Test (V-NET) is a standard test. It measures the academic knowledge and professional standards of the second and third-year level students to group the quality of the learners using mean. The V-NET is designed to capture the quality standard of both teachers and students at the vocational certificate level. The evaluation criteria used the percentage of learners who achieved a grade point average of the national grade point average and compared with the learners who are enrolled in the vocational certificate level. For the academic year 2014-2018, researchers found that the vocational certificate level had an average knowledge test 
score in various testing areas including core competencies and general competencies, components, thinking skills, and problem-solving. The average scores at national level were $35.57,28.45,32.92,30.11$, and 30.56 , respectively, which had the quality level in the criteria for improvement needed. When we consider the area of problemsolving in combination within professional skills using scientific principles and processes, the average scores in these areas were 38.73, 30.31, 39.02, 33.47, and 34.50. In addition, the principles of problem-solving in the profession using mathematical processes achieved average scores of $32.41,26.58,26.83,26.75$, and 26.63 [6]. When comparing these average scores with the national educational test in vocational education between 2013 and 2018, in the areas of thinking skills, components, and problemsolving, the overview of all areas at the national level as well as the overview of the national business computer sectors, researchers found that the overall national business computers had average scores of 32.75, 35.01, 27.29, 32.15, 29.36, and 29.89, respectively. It is quite noticeable that the mean score was lower than the average score in all fields and that the mean score was less than 50.00 . The results are a reflection of Thai academic quality, which is below standard. These workers obviously lack communication skills, critical thinking skills, and problem-solving skills [7].

Gamification is the application of game design principles and mechanisms. The game designates scores as an experience level, with a joint leaderboard including organizing a competition between learners. This concept has been applied in a context that is not game play in the anticipation of stimulating learners, building engagement, and encouraging learners to develop behaviors both in knowledge acquisition and developing skill sets that the designer needs to happen [8]. However, the gamification technique is not intended to change the teaching method to gaming. Rather, it combines game design elements with teaching. The teaching and learning process involves creating a game-like experience to drive learners' involvement with learning and teaching based on the above problems and priorities. The researchers were interested in developing the teaching and learning models using the problem as a basis in conjunction with the gamification concept, to develop the problem-solving skills of high-level vocational students by simulating the playing environment. The learners will receive points or awards when completing the assigned missions.

From the above discussion points, the researchers were interested in developing problem-based learning as a foundation for learners mixed with gamification. The simulation of real situations needed to be constructed. The purpose was to strengthen problem-solving skills among vocational students, including critical thinking, analysis, and making decisions. It also helps the development of the self-learning skill, which is a lifelong learning skill that is important in the 21 st century for workers who are in demand among the entrepreneurs in the labor market.

The objective of this research is to synthesize a problem-based learning model in conjunction with the gamification concept to enhance high-level vocational students' problems-solving skills and evaluate the suitability of the synthetic form of the mixed learning model. 


\section{$2 \quad$ Literature Review}

\subsection{Definition of problem-based learning}

Problem-based learning is a teaching method to equip learners with appropriate knowledge of problem-solving [9]. The approach is student-centered [10]. The problem-solving is used to encourage students to learn or solve problems. The decisionmaking process can be a real problem or a simulated problem that is related to learners' daily life [11]. They may use both new knowledge and prior knowledge in their decisions to solve problems. This allows students to practice thinking and problem analysis. Solving problems together [10] will help learners gain knowledge, use thinking, and develop problem-solving skills [12]. Learners work at all levels with a teacher acting as a facilitator or advisor (guide).

\subsection{Definition of gamification in learning}

Gamification is the application of game design elements and principles of gameplay in a non-gaming context $[14,15,16]$. It is a set of activities and processes to solve problems by applying game processes in problem-solving. In applying game features and elements to attract the target audience into the problem-solving process, the goal is to participate in learning in a fun way $[17,30]$. The purpose is to change behavior and to use activities to build the learning of new skills or the use of innovation [18]. Gartner, Inc. predicts that by the year 2020 gamification will be applied to create a curriculum of global advanced education. Game mechanics will be included in the learning process around the world. The examples of the gamification concept that will be included in learning outcomes are experience points, leaderboards, badges [19], progress bar, and rewards [28]. The outcomes will organize competitions between participants, etc. This is important in the use of gamification, not in technology, but in the environment. Students will learn variety and decision-making systems [20] and both will be rewarded. This gamification learning focuses on motivation, satisfaction, commitment, and taking part in a higher learning process [21, 22].

\subsection{Problem-based Learning with the gamification concept}

Applying the concept of gamification in teaching and learning starts with seeing the common point of games and learning is problem-solving skills. This problem will determine the learning goals of the learners [31]. It also encourages students to pursue active study and to make use of the advanced thinking skills, a learning skill of the 21 st century. Gamification concept is applied in each step of the problem-based learning to provide learners with more fun, satisfaction, and challenges in doing various activities to create strength. It motivates students' interest and creates a greater commitment to learning. 


\subsection{Problem-solving skills}

Problem-solving skills are a systematic thinking process. They involve the intellectual process of determining the root cause of problems then proposing solutions to problems using prior knowledge of the person to help solve an unfamiliar problem situation [23]. The learners choose an appropriate method or process. The process begins with confrontation. When the problem has been answered, it is summarized by considering the conditions that have been determined with the topic of the problem. The learner will need to study, understand, and synthesize problem to be able to apply the process into new or different situations.

\section{$3 \quad$ Methodology}

This research consists of two steps which are synthesis and evaluation of the suitability of managing problem-based learning in conjunction with the gamification concept to enhance problem-solving skills.

Step one: The synthesis of a learning management model has the following steps:

1. Synthesize documents and existing research documents on problem-based learning and the concept of gamification.

2. Design a problem-based learning management model in conjunction with the gamification concept to enhance problem-solving skills.

Step two: Evaluate the suitability of the learning management model with the focus group process by a group of specialists from educational institutions, public and private sectors. We chose a total of nine educational specialists with at least three years of teaching experience and graduates with doctorate degrees who had experience in educational research. These specialists teach computer subjects, education teaching, and learning management. They use problems as a basis in their teaching as well as the management of problem-solving in combination with learning by using the gamification concept.

\section{$4 \quad$ Research Finding}

Step one: The synthesis of a learning management model.

The researcher surveyed documents and research related to problem-based learning amount fourteen papers. The result surveyed present in table 1. The synthesis steps of the learning by using a problem as a base. The management of learning using problems as a base that has been accepted will have a similar approach. However, they may contain differences in details due to the intended purpose and learning objective. We concluded that the steps of learning management by using problems as a base could be divided into five steps as follows:

1. Identify the problem: Students read the situation and take steps on recording vocabularies and messages that they do not understand to identify what are the major problems of the situation. 
2. Analysis of the problem: Learners share their opinions. At the same time, teachers may need to remind or review the subject matter of the learners' prior knowledge. This process will help learners visualize the connection of old knowledge with new knowledge that they do not yet have and want to study. This study framework concurs with the Idea, Facts, Learning Issues and Action plan (IFLA).

2.1 Problem-solving ideas: learners must be able to identify what knowledge they need to study in order to solve the problem from the problem situation.

2.2 Facts: What did the learners identify as facts or fictitious information that appeared in a problem situation? Using knowledge previously learned, help find information in the form of regular sentences.

2.3 Learning issues: learners identify their lack of knowledge. This is areas which they do not understand and where they need explanations of the situation in the form of question sentences.

2.4 Action plan: learners specify how they can learn, from whom, and where in order to use information in answering questions. Learners will assign duties within their group to study various issues to ensure clear implementation and timing of the action.

3. Discovery: Learners will discover by themselves information on the assigned topics. The student conducts self-study in the subject assigned by the source of information. This is prepared according to the interests of the learners who write a summary of the knowledge that they had studied with reference sources.

4. Experiment: Learners will share of their finding from their research study within the group. They will bring the knowledge they have studied to the group for discussion and synthesize the knowledge that has been learnt. Finally, they will be able to answer all the questions that they want to know without doubt. In the case of imperfect answers, where they are still questioning, knowledge must be sought out and they must conduct more research to answer questions using mind maps, which is a tool to help observe, compare, and gather information.

5. Presentation and evaluation of work: Learners present their results in front of peers. Teacher and learners jointly assess the performance. The teacher reflects on the strengths and highlights areas that should be revised to the learners. The students collectively summarize the knowledge gained from problem situations.

Table 1. Synthesis of documents and research related to problem-based learning.

\begin{tabular}{|l|c|c|c|c|c|c|c|c|c|c|c|c|c|c|}
\hline \multicolumn{1}{|c|}{ Step of learning base } & $\mathbf{1}$ & $\mathbf{2}$ & $\mathbf{3}$ & $\mathbf{4}$ & $\mathbf{5}$ & $\mathbf{6}$ & $\mathbf{7}$ & $\mathbf{8}$ & $\mathbf{9}$ & $\mathbf{1 0}$ & $\mathbf{1 1}$ & $\mathbf{1 2}$ & $\mathbf{1 3}$ & $\mathbf{1 4}$ \\
\hline 1. Define the problem & $\mathrm{x}$ & & $\mathrm{x}$ & $\mathrm{x}$ & $\mathrm{x}$ & $\mathrm{x}$ & & $\mathrm{x}$ & $\mathrm{x}$ & $\mathrm{x}$ & $\mathrm{x}$ & $\mathrm{x}$ & $\mathrm{x}$ & $\mathrm{x}$ \\
\hline 2.Understand the problem & $\mathrm{x}$ & & $\mathrm{x}$ & $\mathrm{x}$ & $\mathrm{x}$ & $\mathrm{x}$ & $\mathrm{x}$ & & $\mathrm{x}$ & & & $\mathrm{x}$ & $\mathrm{x}$ & \\
\hline 3. Linking problems / brainstorm & & $\mathrm{x}$ & & & & $\mathrm{x}$ & & & $\mathrm{x}$ & $\mathrm{x}$ & $\mathrm{x}$ & & $\mathrm{x}$ & \\
\hline 4. Analyze the problem and make assumptions & $\mathrm{x}$ & & $\mathrm{x}$ & $\mathrm{x}$ & & $\mathrm{x}$ & & & $\mathrm{x}$ & & & $\mathrm{x}$ & $\mathrm{x}$ & $\mathrm{x}$ \\
\hline 5. Set objectives / define issues in learning & & $\mathrm{x}$ & $\mathrm{x}$ & & & $\mathrm{x}$ & & & $\mathrm{x}$ & & $\mathrm{x}$ & $\mathrm{x}$ & $\mathrm{x}$ & $\mathrm{x}$ \\
\hline $\begin{array}{l}\text { 6. Separate already known from not known of } \\
\text { problem / method of acquiring the information }\end{array}$ & & & $\mathrm{x}$ & $\mathrm{x}$ & & & $\mathrm{x}$ & & & $\mathrm{x}$ & & & & \\
\hline 7. Record what to research / conducting research & $\mathrm{x}$ & $\mathrm{x}$ & $\mathrm{x}$ & $\mathrm{x}$ & $\mathrm{x}$ & $\mathrm{x}$ & $\mathrm{x}$ & $\mathrm{x}$ & $\mathrm{x}$ & $\mathrm{x}$ & & $\mathrm{x}$ & $\mathrm{x}$ & $\mathrm{x}$ \\
\hline $\begin{array}{l}\text { 8. Consider the } \\
\text { information obtained and decide on the choices }\end{array}$ & & $\mathrm{x}$ & & & & & & & & & $\mathrm{x}$ & & & \\
\hline 9. Knowledge & $\mathrm{x}$ & & & & $\mathrm{x}$ & & & $\mathrm{x}$ & $\mathrm{x}$ & $\mathrm{x}$ & $\mathrm{x}$ & $\mathrm{x}$ & & \\
\hline
\end{tabular}




\begin{tabular}{|l|c|c|c|c|c|c|c|c|c|c|c|c|c|c|}
\hline \multicolumn{1}{|c|}{ Step of learning base } & $\mathbf{1}$ & $\mathbf{2}$ & $\mathbf{3}$ & $\mathbf{4}$ & $\mathbf{5}$ & $\mathbf{6}$ & $\mathbf{7}$ & $\mathbf{8}$ & $\mathbf{9}$ & $\mathbf{1 0}$ & $\mathbf{1 1}$ & $\mathbf{1 2}$ & $\mathbf{1 3}$ & $\mathbf{1 4}$ \\
\hline synthesis & & & & & & & & & & & & & & \\
\hline $\begin{array}{l}\text { 10. Creating a } \\
\text { portfolio or practicing the options }\end{array}$ & $\mathrm{x}$ & $\mathrm{x}$ & $\mathrm{x}$ & $\mathrm{x}$ & & & & & $\mathrm{x}$ & $\mathrm{x}$ & $\mathrm{x}$ & $\mathrm{x}$ & & \\
\hline $\begin{array}{l}\text { 11. Summarize and evaluate the value of } \\
\text { the answer }\end{array}$ & & $\mathrm{x}$ & $\mathrm{x}$ & & $\mathrm{x}$ & & & & $\mathrm{x}$ & & $\mathrm{x}$ & & & $\mathrm{x}$ \\
\hline 12. Presentation and evaluation & & & $\mathrm{x}$ & $\mathrm{x}$ & $\mathrm{x}$ & $\mathrm{x}$ & $\mathrm{x}$ & $\mathrm{x}$ & & $\mathrm{x}$ & & & $\mathrm{x}$ & $\mathrm{x}$ \\
\hline
\end{tabular}

Note: columns define: 1. Schmidt (1983), 2. Robert Delisle (1997), 3. Oon-Seng Tan (2003), 4. ETE-GCC Team (2019), 5. Office Secretary Education Council (2007), 6. Gino Camp et al (2014), 7. Polya (2018), 8. Khemmanee (2007), 9. Anuphalekakul (2005), 10. Phisit Suwanpane (2014), 11. Sikharin Thankotsingha et al. (2014), 12. Wim Gijselaers (1995), 13. Thipwan Sutin (2012), 14). Kaiasit Apirating (2015)

Next step, the researcher surveyed of documents and research related to gamification by using problems amount fifteen papers. The result surveyed present in table 2.

Table 2. Synthesis of documents and research related to gamification by using problems.

\begin{tabular}{|l|c|c|c|c|c|c|c|c|c|c|c|c|c|c|}
\hline Gamification Mechanism & $\mathbf{1}$ & $\mathbf{2}$ & $\mathbf{3}$ & $\mathbf{4}$ & $\mathbf{5}$ & $\mathbf{6}$ & $\mathbf{7}$ & $\mathbf{8}$ & $\mathbf{9}$ & $\mathbf{1 0}$ & $\mathbf{1 1}$ & $\mathbf{1 2}$ & $\mathbf{1 3}$ & $\mathbf{1 4}$ \\
\hline Experience Point & $\mathrm{x}$ & $\mathrm{x}$ & $\mathrm{x}$ & $\mathrm{x}$ & $\mathrm{x}$ & & $\mathrm{x}$ & $\mathrm{x}$ & $\mathrm{x}$ & $\mathrm{x}$ & $\mathrm{x}$ & $\mathrm{x}$ & $\mathrm{x}$ & $\mathrm{x}$ \\
\hline Player Level & $\mathrm{x}$ & $\mathrm{x}$ & $\mathrm{x}$ & $\mathrm{x}$ & & & $\mathrm{x}$ & $\mathrm{x}$ & $\mathrm{x}$ & $\mathrm{x}$ & & $\mathrm{x}$ & & $\mathrm{x}$ \\
\hline Badge or Medal & $\mathrm{x}$ & $\mathrm{x}$ & $\mathrm{x}$ & $\mathrm{x}$ & $\mathrm{x}$ & $\mathrm{x}$ & $\mathrm{x}$ & $\mathrm{x}$ & $\mathrm{x}$ & $\mathrm{x}$ & $\mathrm{x}$ & $\mathrm{x}$ & $\mathrm{x}$ & $\mathrm{x}$ \\
\hline Challenge & $\mathrm{x}$ & & $\mathrm{x}$ & & $\mathrm{x}$ & & & $\mathrm{x}$ & & & & $\mathrm{x}$ & $\mathrm{x}$ & $\mathrm{x}$ \\
\hline Score Board & $\mathrm{x}$ & & $\mathrm{x}$ & $\mathrm{x}$ & $\mathrm{x}$ & & $\mathrm{x}$ & $\mathrm{x}$ & $\mathrm{x}$ & $\mathrm{x}$ & $\mathrm{x}$ & $\mathrm{x}$ & $\mathrm{x}$ & $\mathrm{x}$ \\
\hline Rules & & $\mathrm{x}$ & $\mathrm{x}$ & $\mathrm{x}$ & $\mathrm{x}$ & & & $\mathrm{x}$ & $\mathrm{x}$ & $\mathrm{x}$ & $\mathrm{x}$ & $\mathrm{x}$ & $\mathrm{x}$ & $\mathrm{x}$ \\
\hline Objective & & $\mathrm{x}$ & & & $\mathrm{x}$ & & & & & & $\mathrm{x}$ & & & \\
\hline Avatar Creation & & & & & & & & & $\mathrm{x}$ & & & $\mathrm{x}$ & & \\
\hline Reward Simulation & & & & $\mathrm{x}$ & $\mathrm{x}$ & & & $\mathrm{x}$ & & & & & & \\
\hline Progress Graph & & & & & $\mathrm{x}$ & $\mathrm{x}$ & & & $\mathrm{x}$ & & & $\mathrm{x}$ & & \\
\hline Reflection & & $\mathrm{x}$ & & & & & & $\mathrm{x}$ & & & $\mathrm{x}$ & & $\mathrm{x}$ & \\
\hline Duty & $\mathrm{x}$ & & & & & $\mathrm{x}$ & & $\mathrm{x}$ & & $\mathrm{x}$ & & & & \\
\hline Player Introduction & & & & $\mathrm{x}$ & & & & $\mathrm{x}$ & & & & & & \\
\hline Competition & & $\mathrm{x}$ & & & $\mathrm{x}$ & & & $\mathrm{x}$ & & & & & & \\
\hline Timing & & $\mathrm{x}$ & & & $\mathrm{x}$ & $\mathrm{x}$ & & & & & & & & \\
\hline Story & & $\mathrm{x}$ & & & $\mathrm{x}$ & & & & & & & & & \\
\hline Virtual Agent & & & & & & $\mathrm{x}$ & & & & & & & & \\
\hline Greeting & & & & & & $\mathrm{x}$ & & & & & & & & \\
\hline
\end{tabular}

Note: columns define: (1) Zichermann (2011), (2) Kapp (2012), (3) Barata (2013), (4) Simões (2013), (5) Donovan (2013), (6) Utomo (2015), (7) A. Losup (2014), (8) Lincoln C. Wood (2015), (9) F.L. Khaleel (2016), (10) Santana (2016), (11) L.C. Stanculescu (2016), (12) Yuan Jia (2016), (13) Oscar Wongso (2014), (14) Suchanya Yungklang (2019)

Table 2 exhibits the Game Fusion Concept Synthesis. To summarize, this table shows that the game-play concept can be used in classroom management through experience points, progress graph, badges and/or medals, score boards, and competition levels. In the design of learning styles based on the concept of gamification the researchers used a systematic approach to classify the elements and arrange their relationships. The systematic approach process contains the input, process, and output, as shown in Figure 1. 


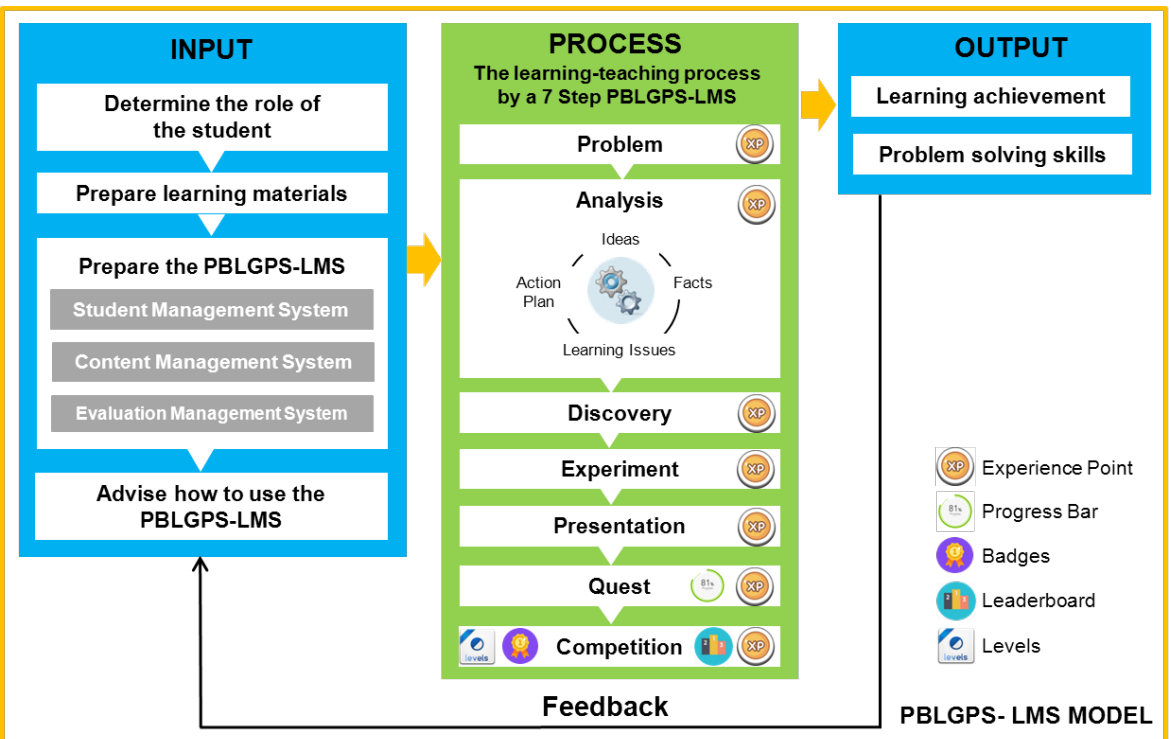

Fig. 1. Model of the PBLGPS-LMS online system

\section{Input}

Input process of the determination includes the following:

1. Determine the role of the student by defining the learner's rules and regulations, preliminary agreements, learning objectives, and content areas. Learning objectives must be studied in every unit. Define roles of learners in the teaching and learning process to make the learning system most effective. Consequently, learners have to make decisions and decide what to study or learn. Instructor acts as a facilitator or an advisor (guide).

2. Prepare learning materials.

2.1 Preparation of learners' understanding of the knowledge-based teaching and learning models and the use of information technology for learning and teaching.

2.2 Prepare a learning action plan as well as an activity plan in which the teacher determines the format of the activities in accordance with the objective and purpose of the material matters.

2.3 Prepare challenging problem situations for learners in problem-solving situations. Learners will be given a problem situation in each unit to study and must try to solve it according to the teaching process.

2.4 Prepare a learning resource such as web information, video clips, lessons, files, PDF, books and teaching materials.

2.5 Prepare a computer and internet network system which consists of a host computer (server). The teaching method has been developed according to the learning model and connects the internet to various clients to enable learners to practice learning activities at any time. 
3. Prepare the PBLGPS-LMS learning system, consisting of the following:

3.1 Student management system helps manage all student information including personal information, progress reports for each activity, experience points reported, levels report, and badges reported from the competition.

3.2 Content management system from the analysis of course objectives, competencies courses, and course descriptions. This can be divided into 12 units and stored in a web document format. Video clips, lessons, and PDFs.

3.3 Evaluation management system consisting of the following:

1) Pre-test consists of 40 questions with four multiple choices. The result will be used to divide students into groups. The criterion for grouping is mixed-ability, low to high skills in one group of three to five learners. This depends on the number of learners in the classroom, proportion $1: 2: 1$, with the following criteria: score less than or equal to $50 \%$ is in the weak category, $51 \%$ to $79 \%$ is in the moderate category, and scores greater than or equal to $80 \%$ are among the best (high skill).

2) Pre- and post-learning problem-solving skills assessment form. The assessment form consists of four choices with ten condition situations of four questions, total of 40 questions. By using these questions, the participants will be able to identify and confine the situations in the computer situation to both hardware and software issues that learners are facing in their daily lives.

3) A problem-solving skill assessment (Quest) of each unit to measure the problem-solving skills of learners.

4) Quiz assigned during class of each unit of study.

4. Suggestion of how to use the PBLGPS-LMS learning system.

4.1 System for scoring experience points and levels to help learners understand scoring system in learning outcome. The criteria will convert the experience points into eight levels. For example, the interval of the scales will be between zero and two which equals to three points, the interval of the scales will be between zero and two which equals to three points, the interval of the scales will be between three and four which equals to two points, and the interval of the scales will be between five and nine which equals to five points, as shown in Table 1 Synthesis of documents and research related to problem-based learning. This research study uses 31 levels as shown in Figure 2 Mechanisms for grading and converting points to grades. 


\begin{tabular}{|c|c|c|c|}
\hline Score & Grade & $\mathbf{X P}$ & Level \\
\hline $0-2$ & 0 & $0-29$ & 1 \\
\hline $3-4$ & 0 & $30-49$ & 2 \\
\hline $5-9$ & 0 & $50-99$ & 3 \\
\hline & $\ldots$ & $\ldots$ & $\ldots$ \\
\hline 9 & $\cdots$ & $\cdots$ & \\
\hline $90-92$ & 4 & $900-929$ & 28 \\
\hline $93-94$ & 4 & $930-949$ & 29 \\
\hline $95-99$ & 4 & $950-999$ & 30 \\
\hline 100 & 4 & 1,000 & 31 \\
\hline
\end{tabular}

Fig. 2. Mechanisms for grading and converting points to grades.

4.3 Explain the activities in the 12 situations; this comprises five stages for each situation. Analysis of the course objectives, course performance and course descriptions can be divided into 12 units of learning thinking units. Problemsolving skills will score at 15 points and the group participation score is 0.5 .

4.3 Explain how to perform the activity which comprises 12 main missions. Each mission will have three activities. Reward scores include one star worth five points, two stars worth five points, and three stars worth seven points; in total 15 points.

4.4 How to make a quiz for the learner who reviews knowledge. The review unit for each lesson has ten questions. Learners will take the quiz after performing the activities of five missions. For all stage activities, the points collected will be accounted for individually with ten points for each stage. The competition consists of two sub-stages.

- Stage 1 - Learners have to defeat all avatars. There will be questions raised for the learners to repeat; these will be simple questions to allow the learner to review and collect the number of experience points when the avatar is defeated. There are total of ten questions with ten avatars. The activity will take five minutes. In order to move to stage two, there are two cases: 1) When the time is up (five minutes) and 2) When all monsters are eliminated.

- Stage 2 - Learners have to finish by answering ten questions in the system.

4.5 A method of rewarding learners by giving badges to demonstrate their ability to perform an activity that relates to problem situations. The criteria for rewarding a badge is $80 \%$. Figure 3 is an example of the symbol in the badges. 


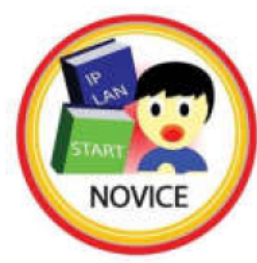

Name of the badge: Novice standing of teaching system

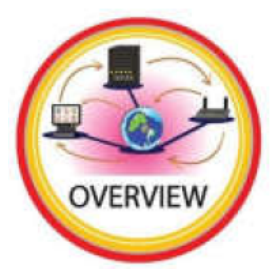

Name of the badge: Overview

Characteristics of the badge: Acknowledge a principle of networking system

Fig. 3. Example of the badges' names and characteristics to exhibit the understanding and acknowledgement

4.6 Professional skills training are a workshop activity with a networking expert. The experts will give a lecture on how to use network equipment. Then, learners will separate into groups to compete with each other in building network systems. The score to collect with this activity is 100 points.

4.7 To calculate the proportion of the score from the collected score to be used to calculate the experience fee.

$$
A=\frac{B}{C} \times D
$$

The criteria are:

1. Proportion 1 point score is equal to $10 \mathrm{XP}$ experience fee

2. A represents the proportion of points obtained from the activity

3. B represents the points collected from activity

4. C represents the collected score

5. D represents the score proportion

For example, hypothetically, a learner takes a pre-test and receives a 20 score (B) out of 40 (full score) (C) proportionally, the score of this activity is 10 , the proportion the learner will earn is $(20 / 40) * 10=0.5$. Then, this value of 0.5 will be multiplied by 10 , and the students will receive experience fees equal to $5 \mathrm{XP}$. In table 2 show summaries of experience points in activity. 
Table 3. Summary of experience points in activity

\begin{tabular}{|c|c|c|c|}
\hline Activity & $\begin{array}{l}\text { Collected score } \\
\text { (C) }\end{array}$ & $\begin{array}{c}\text { Score in } \\
\text { proportion }\end{array}$ & Experience fee \\
\hline 1. Pre-test & 40 & 10 & 10 \\
\hline 2. Evaluation on problem-solving skill (Pre-test) & 40 & 1 & 10 \\
\hline 3. Evaluation on problem-solving skill (Post-test) & 40 & 1 & 10 \\
\hline 4. Situations: 5 stages with 12 activities & $15 * 12=180$ & 10 & 100 \\
\hline 5. Quiz: 12 situations with 10 questions per situation & $10 * 12=120$ & 15 & 150 \\
\hline 6. Main duty: 12 Quests & $15 * 12=180$ & 10 & 100 \\
\hline 7. Badge's collection: 12 coins & $1 * 12=12$ & 6 & 60 \\
\hline 8. Attending class 18 times & 18 & 10 & 100 \\
\hline $\begin{array}{l}\text { 9. Attending class according to system offer } 12 \\
\text { times }\end{array}$ & $10 * 12=120$ & 10 & 100 \\
\hline 10. Professional skills competition & 100 & 10 & 100 \\
\hline 11. Participation & 12 & 7 & 70 \\
\hline 12. Post-test & 40 & 10 & 100 \\
\hline Total & 902 & 100 & 1000 \\
\hline
\end{tabular}

4.8 Introduction of how to register into the learning management system. Learner will apply for membership to gain access to the system to trial various learning functions.

\section{Process}

The process consists of teaching and learning steps using problems as a base together with the concept of gamification. Before starting, the system will randomly assign a group of three to five people. This is designed to allow learners to help each other within the group and also to ensure group collaboration works smoothly and efficiently, as well as enables them to express various opinions. The teaching process consists of seven steps as follows:

Step 1: Problem identification. Learners read the situation and start recording vocabulary and passages where they want to acquire more understanding and that are important for the situation; for example, what is the problem? (Experience point).

Step 2: Analysis of the problem. Students share their opinions at some time. Then, teachers may need to review their prior knowledge. This will allow learners to visualize the connection of old knowledge with new knowledge that they do not yet have and that they want to study more. This relates to the concept of the four educational frameworks, Ideas, Facts, Learning and Action (IFLA).

1. Guidelines for solving problems (Ideas). Learners must be able to identify related knowledge that they need to study in order to be able to solve the situation.

2. Facts. Learners must identify the facts in a problem situation by using their existing knowledge in regular sentences.

3. Learning Issues. Learners must identify questions and/or the areas that they do not understand in the situation problem in the interrogative form.

4. Action Plan. The learners specify how they can learn more information, from whom and where it can be used in answering questions and share this duty within the group 
to study various issues. Operational goals and duration must be set for a clear direction (Experience Point).

Step 3: Discovery. Learners conduct self-study that they are given with the sources of information provided. The topic is designated according to the interest of learners. Then, the learners will write a summary of the knowledge that they have studied including reference sources (Experience Point).

Step 4: The experiment consists of the following steps:

1. Learners join together to synthesize the knowledge of each person within the group and set problem-solving steps.

2. Teacher randomly picks a group member to present the results of the synthesis in the form of a mind map. Learners join in the discussion and conclude the operational steps.

3. Learners continue to solve problem situations according to steps (Experience Point).

Step 5: Presentation and Evaluation

1. Teacher randomly chooses a person from each group to present in front of the classroom.

2. Teacher and learners evaluate result from the learning outcome. Then, teacher reflects on strong points as well as the areas of improvement the learners need to address. This will help learners in developing and improving next time.

3. Teachers and learners together summarize the knowledge gained from problem situations by using a group mind map. Then, students save their information into the system.

\section{Step 6: Quests}

Teachers have learners evaluate their problem-solving skills by completing planned missions in the city map activity through the game application. The mission consists of three sub-missions (Experience points) and progress bar to show the improvement.

Step 7: Competition

1. Teacher organizes a contest to answer the questions of each unit through application games which learners have to log into the system to enter the competition. There are two modes, which are an easy mode and a hard mode.

2. The criteria for passing the competition activity is $60 \%$. If below $60 \%$, the system will advise learner to perform more research from various sources, which are in different formats such as pdf files, videos, web documents. In cases where the learners keep scoring $80 \%$ or more, they will get a badge to show talent (Experience point, Leaderboard, Badges and Levels). 


\section{Output}

Output is the result obtained from the teaching and learning process as follows:

1. Learning achievement. The method for evaluating and assessing learning achievement is pre-test and post-test.

2. Problem-solving skills. There are two parts in the evaluation. 1) Use an assessment form of problem-solving skills before and after learning and 2) Evaluation form for problem-solving skill assessments (Quest) of each unit.

\section{Feedback}

Feedback is the result of mission performance and activity errors.

Step two: Evaluate the suitability of the learning management model.

This step evaluates the suitability of the design for learning style. The researcher chose the focus group to evaluate the best learning approach. The opinions from experts were collected using the five-rating scale questionnaire. The steps for this process are as follows: 1) Create a tool to evaluate the suitability of the learning style. 2) Select of nine experts who hold doctoral degrees, work as lecturers at universities, and have at least three years' relevant experience. 3) Evaluate the suitability of the learning style with focus group discussion with nine experts. 4) Analyze the results of the evaluation of suitability using mean. The results of assessment of experts in learning style are present in the table 4.

Table 4. Results of the suitability assessment of the learning style

\begin{tabular}{|l|c|l|}
\hline \multicolumn{1}{|c|}{ Evaluated contents } & Average & \multicolumn{1}{|c|}{ Category } \\
\hline Input & 4.66 & Very Good \\
\hline 1. Determine the role of the student & & \\
1.1 Explaining rules and the basis of the agreement to students & 4.89 & Very Good \\
1.2 Conducting the learners' role in the learning and teaching process & 4.67 & Very Good \\
\hline 2. Prepare learning materials & & \\
2.1 Learners' readiness & 4.67 & Very Good \\
2.2 Lesson plan readiness & 4.89 & Very Good \\
2.3 Prepare problem situation for activity & 4.78 & Very Good \\
2.4 Prepare on learning sources & 4.33 & Good \\
\hline 3. Prepare the PBLGPS-LMS & & \\
3.1 Student management system & 4.78 & Very Good \\
3.2 Content management system & 4.78 & Very Good \\
3.3 Evaluation management system & 4.78 & Very Good \\
\hline 4. Advice how to use the PBLGPS-LMS & & \\
4.1 Experience point and level calculation & 4.67 & Very Good \\
4.2 Explain activity in each stage & 4.78 & Very Good \\
4.3 Explain how quest generates & 4.56 & Very Good \\
4.4 Explain how to take quiz & 4.67 & Very Good \\
4.5 Explain how to give badges & 4.22 & Good \\
4.6 Explain how to compete in professional skills competition & 4.44 & Good \\
\hline Process & 4.78 & Very Good \\
\hline 1. Identifying problem & 4.78 & Very Good \\
\hline 2. Analyzing situation & & \\
2.1 Ideas of problem-solving guideline & 4.78 & Very Good \\
2.2 Fact finding & 4.67 & Very Good \\
2.3 Additional learning issues (areas) & 4.78 & Very Good \\
\hline
\end{tabular}


Paper-The Synthesis of a Model of Problem-Based Learning With the Gamification Concept..

\begin{tabular}{|l|c|l|}
\hline \multicolumn{1}{|c|}{ Evaluated contents } & Average & \multicolumn{1}{c|}{ Category } \\
\hline 2.4 Action planning on research study & 4.56 & Very Good \\
\hline 3. Research discovery & 4.56 & Very Good \\
\hline 4. Research experiment & 4.89 & Very Good \\
\hline 5. Presentation and evaluation & 5.00 & Very Good \\
\hline 6. Activity quest & 4.89 & Very Good \\
\hline 7. Competition level & 4.67 & Very Good \\
\hline Output & 4.78 & Very Good \\
\hline 1. Learning achievement & 4.78 & Very Good \\
\hline 2. Problem-solving skills & 4.78 & Very Good \\
\hline Summary of the suitability level on overall learning style & 4.73 & Very Good \\
\hline
\end{tabular}

Table 4 shows that the suitability level of the overall learning style was in the very appropriate level at the end $($ Mean $=4.73)$. In the results of consideration by aspect, for example, the input factor has a suitability level of learning style at very good (Mean $=4.66$ ). Both process and outcome factors have a suitability level of learning style at very good with both Mean equal to 4.78 .

\section{Summary}

This research evaluated the suitability of learning styles from nine experts by discussion among the focus group. We found that the result of this study process is the most appropriate and is able to apply patterns to teaching and learning to the actual learners. Teaching properly repeating this learning style can emphasize the problemsolving skills among the learners. The problems in the lesson activity design were developed from various situations. Situations in each learning activity were defined by using problem-based teaching and learning together with the gamification concept. This teaching technique was used to motivate the learners interested in learning, to enhance their engagement in studying and to promote learning and problem-solving by using the whole teaching and learning process.

There are seven steps in the learning activity and the problem-solving activity: 1) Problem, 2) Analysis, 3) Discovery, 4) Experiment, 5) Presentation, 6) Quest, and 7) Competition. When the learners participate in the activity, they will be given experience points to use in level playing. Badges were given to show that the learners have passed the requirement of the activity. This is consistent with Barata's research comparing two groups of learners, one who did not use the concept of gamification and another who did use the concept of gamification in their teaching and learning. It was found that the group using the gamification concept had better academic performance [29]. The process was able to increase motivation and motivate learners to be interested in the lessons [25]. This indicates not only the ability of the learner, but also the improvement of learners' skills in problem-solving. Learners who receive the highest score of ten will be shown in the leaderboard. Those who have less experience points will try to compete in order to gain their name at the top [24,26,27] of the user names displayed on the leaderboard. In order to protect the learner from embarrassment and 
maintain privacy, the name on the leaderboard is a nickname which was given at the beginning of the activity [26].

\section{Acknowledgement}

The researchers would like to express sincere gratitude and deep appreciation to their instructors in the Department of Computer Education, Faculty of Technical Education, as well as to the experts who participated in discussions. Thank you again to the authors of the research articles, case studies, textbooks, and other useful sources of information that we consulted as part of our study.

\section{$7 \quad$ References}

[1] Office of the National Economic and Social Development Board (2016) 35-36.

[2] Office of the Education Council Secretariat (2017). National Education Plan for 20172036, Bangkok, Thailand. 1st Edition.

[3] Partnership for 21st Century Learning. (2019). Framework for 21st Century Learning. Retrieved from http://www.battelleforkids.org/networks/p21/frameworks-resources .

[4] Office of Knowledge Management and Development, in collaboration with the KMUTT Learning Institute (2017). Learning model for new generation. Retrieved from https://celt.li.kmutt.ac.th/research/okmd1/km/wp-content/uploads/2016/11/161107-okmdproposal-bykmutt-SLIDES.pdf

[5] Electronic Transactions Development Agency of Thailand (ETDA). (2019). Retrieved from https://www.etda.or.th/

[6] National Institute of Educational Testing Service (NIETS). (2019). Retrieved from www.niets.or.th/

[7] Dailynews (2018). The Analysis of VNET. Vocational Education Commission. April 25, 2018. Retrieved from https://www.dailynews.co.th/education/640000

[8] Simões, J., Redondo, R. D., \& Vilas, A. F. (2013). A social Gamification framework for a K-16 learning platform. Computer in Human Behavior, 29(2), 345-353. Retrieved from https://doi.org/10.1016/j.chb.2012.06.007

[9] Schmidt, HG. (1983). Problem-based learning: Rationale and description. Medical Education. 17:11-6.

[10] Kurt, S. Problem-Based Learning (PBL) (2020). Educational Technology, January 8, 2020. Retrieved from https://educationaltechnology.net/problem-based-learning-pbl/

[11] Office of the Education Council (2007). Problem-Based Learning Management. Bangkok, Thailand. 1st Edition. Retrieved from http://www.onec.go.th/

[12] Khaemmanee, T. (2007). Teaching Science: Knowledge to organize an effective learning process. Bangkok: Publisher of Chulalongkorn University. Type once (revised version).

[13] Lekhakula, A. (2005). Problem-Based Learning. Retrieved from http://teachingresources.psu.ac.th/document/2548/Le Kha Kun/PBL.pdf

[14] Robson, K., Plangger, K., Kietzmann, J., McCarthy, I., \& Pitt, L. (2015). Is it all a game? Understanding the principles of gamification. Business Horizons. 58 (4): 411-420. Retrieved from https://doi.org/10.1016/j.bushor.2015.03.006

[15] Stott, A.J., \& Neustaedter, C. (2013). Analysis of Gamification in Education. Retrieved from http://clab.iat.sfu.ca/pubs/Stott-Gamification.pdf 
[16] Deterding, S., Dixon, D., Khaled, R., \& Nacke, L. (2011). From game design elements to gamefulness: Defining 'gamification'. Proceedings of the 15th International Academic MindTrek Conference. pp. 9-15. Retrieved from https://doi.org/10.1145/2181037.2181040

[17] Kim, A.J. (2011, March 23). Gamification 101: Designing the player journey. Google Tech Talk. Retrieved from https://youtu.be/B0H3ASbnZmc

[18] Ignatius T. (2014). Building Engaging Web Apps with Game Mechanics. Retrieved from https://www.sitepoint.com/building-engaging-web-apps-game-mechanics /

[19] Gartner, Inc. (2012). Gamification 2020: What Is the Future of Gamification? Retrieved May 3, 2020 from https://www.yumpu.com/en/document/view /12000546/gamification-2020-what-is-the-future-of-gamification

[20] Kapp, K. M. (2012). The Gamification of learning and instruction: game-based methods and strategies for training and education. John Wiley \&Sons.

[21] Urh, M., Vukovic, G., Jereb, E., \& Pintar, R. (2015). The Model for Introduction of Gamification into E-learning in Higher Education. 7th World Conference on Educational Sciences (388-397). Science Direct. Retrieved from https://doi.org/10.1016/j.sbspro.2015.07 .154

[22] Simões, J., Redondo, R. D., \& Vilas, A. F. (2013). A social Gamification framework for a K-16 learning platform. Computer in Human Behavior, 29(2), 345-353. Retrieved from https://doi.org/10.1016/j.chb.2012.06.007

[23] Krulik, S., \& Rudnick, J. A. (1988). Problem Solving: A Handbook for elementary school teachers. Allyn and Bacon.

[24] Barata, G., Gama S., Jorge J., \& Goncalves. (2013). Improving Participation and Learning with Gamification. Stratford, ON, Canada. October 2-4. Doi: http://dx.doi.org/10.1145/ $\underline{2583008.2583010}$

[25] Losup, A., \& Epema, D. (2014). An Experience Report on Using Gamification in Technical Higher Education. SIGCSE' 14, March 3-8, Atlanta, GA, USA.

[26] Donovan A., Gain J., \& Marais P. (2013). A Case study in the gamification of a University-level games development course. SAICSIT'13, October 07-09, East London, South Africa. Retrieved from http://dx.doi.org/10.1145/2513456.2513469

[27] Wood, L. C., \& Reiners, T. (2015). Gamification. In M. Khosrow-Pour(Ed.), Encyclopedia of Information Science and Technology (3rd ed., 3039-3047) https://doi.org/10.4018/978$\underline{1-4666-5888-2 . \operatorname{ch} 297}$

[28] Panis I.C., Setyosari P., Kuswandi D., \& Yuliati L. (2020). Design Gamification models in Higher Education: A Study in Indonesia. International Journal of Emerging Technologies in Learning. iJet - Vol.15(12), 244-255. Retrieved from https://doi.org/10.3991/ijet.v15 $\underline{\mathrm{i} 12.13965}$

[29] uran Z., Avinc Z., Kara Kadir., \& Goktas Y. (2016). Gamification and Education: Achievements, Cognitive Loads, and Views of Students. International Journal of Emerging Technologies in Learning. iJet - Vol.11(7), 64-69. Retrieved from https://dx.doi.org/ 10.3991/ijet.v11i07.5455

[30] Arce N.P.H \& Valdivia A.M.C. (2020). Adapting Competitiveness and Gamification to a Digital Platform for Foreign Language Learning. International Journal of Emerging Technologies in Learning. iJet - Vol.15(20), 194-209. Retrieved from https://doi.org/10.39 91/ijet.v15i20.16135

[31] Fabricatore, C., \& López, X., (2014). Using Gameplay Patterns to Gamify Learning Experiences. In The European Conference on Games Based Learning. Academic Conferences \& Publishing International. 


\section{Authors}

Ratchapol Kladchuen is a Ph.D. student in Department of Computer Education, Faculty of Technical Education, King Mongkut's University of Technology North Bangkok (KMUTNB), Thailand (e-mail: pmc.ratchapol@gmail.com). He works as a special instructor at the Pranakorn Commercial Technological College, Bangkok, Thailand.

Jiraphan Srisomphan is an assistant Professor at Department of Computer Education, Faculty of Technical Education, King Mongkut's University of Technology North Bangkok (KMUTNB), Thailand (e-mail: jiraphan.s@fte.kmutnb.ac.th ). He has been working as a teacher for more than 20 years in the field of information technology and computer education at Faculty of Technical Education, King Mongkut's University of Technology North Bangkok (KMUTNB), Thailand. Jiraphan.s@fte.kmutn $\underline{\text { b.ac.th }}$

Article submitted 2020-12-10. Resubmitted 2021-04-14. Final acceptance 2021-04-20. Final version published as submitted by the authors. 